\title{
Is the impact of eutrophication on phytoplankton diversity dependent on lake volume/ecosystem size?
}

\author{
Didier L. BAHO,${ }^{1,2^{*}}$ Stina DRAKARE,${ }^{1}$ Richard K. JOHNSON,${ }^{1}$ Craig R. ALLEN, ${ }^{3}$ David G. ANGELER ${ }^{1}$ \\ ${ }^{1}$ Swedish University of Agricultural Sciences, Department of Aquatic Sciences and Assessment, PO Box 7050, SE-750 07 Uppsala, \\ Sweden; ${ }^{2}$ Norwegian Institute for Water Research, Gaustadalléen 21, NO-0349 Oslo, Norway; ${ }^{3}$ U.S. Geological Survey, Nebraska \\ Cooperative Fish and Wildlife Research Unit, School of Natural Resources, University of Nebraska-Lincoln, Lincoln, NE, USA \\ *Corresponding author: didier.baho@niva.no
}

\begin{abstract}
Research focusing on biodiversity responses to the interactions of ecosystem size and anthropogenic stressors are based mainly on correlative gradient studies, and may therefore confound size-stress relationships due to spatial context and differences in local habitat features across ecosystems. We investigated how local factors related to anthropogenic stressors (e.g., eutrophication) interact with ecosystem size to influence species diversity. In this study, constructed lake mesocosms (with two contrasting volumes: 1020 (shallow mesocosms) and 2150 (deep mesocosms) litres) were used to simulate ecosystems of different size and manipulated nutrient levels to simulate mesotrophic and hypertrophic conditions. Using a factorial design, we assessed how the interaction between ecosystem size and nutrients influences phytoplankton diversity. We assessed community metrics (richness, diversity, evenness and total biovolumes) and multivariate community structure over a growing season (May to early November 2011). Different community structures were found between deep and shallow mescosoms with nutrient enrichment: Cyanobacteria dominated in the deep and Charophyta in the shallow mesocosms. In contrast, phytoplankton communities were more similar to each other in the low nutrient treatments; only Chlorophyta had generally a higher biovolume in the shallow compared to the deep mesocosms. These results suggest that ecosystem size is not only a determinant of species diversity, but that it can mediate the influence of anthropogenic effects on biodiversity. Such interactions increase the uncertainty of global change outcomes, and should therefore not be ignored in risk/impact assessment and management.
\end{abstract}

Key words: Eutrophication; shallow lakes; ecosystem size; impact assessment; phytoplankton; global climate change.

Received: August 2016. Accepted: October 2016.

\section{INTRODUCTION}

Lakes can be regarded as islands within a matrix of terrestrial land cover (Dodson, 1992) and numerous observational lake gradient studies support species area theory: aquatic bacteria (Bell et al., 2005; Reche et al., 2005), phytoplankton (Søndergaard et al., 2005), zooplankton (Dodson, 1992; Keller and Conlon, 1994), fish (Tonn and Magnuson, 1982; Post et al., 2000; Ingram et al., 2012), submerged vegetation (Rørslett, 1991) and birds (Hoyer and Canfield, 1994). Despite the consistency of results across taxonomic groups, species-area relationship has traditional been tested in a two-dimensional habitats, which do not hold in lenthic ecosystems as they have an additional vertical dimension (water column), making diversity predictions more complex (Drakare et al., 2006). The species sorting paradigm of metacommunity ecology stresses the dominant role of local habitat factors on community composition and biodiversity (Leibold et al., 2004; Elliott et al., 2007; Soininen, 2014). For instance, in lakes an assessment of size effects on species richness can be confounded by the interactions of lake volume with other variables (acidity and nutrient status) (Sprules, 1977; Confer et al., 1983; Søndergaard et al., 2005). The importance of many of these in-lake variables (e.g., trophic condition) can be magnified through global change stressors (e.g., eutrophication) that can result in dramatic changes in the abiotic and biotic environment of lakes (Hansen et al., 2001). The resulting changes may lead to interactions with ecosystem size that could affect community structure (Angeler and Alvarez-Cobelas, 2005). Cause-effect relationships between biodiversity, natural and anthropogenic factors cannot be explored by observational studies alone (Frost et al., 1988). Experimental approaches can discern whether the role of global stress impacts is dependent on ecosystem size by controlling for potential confounding effects of spatial context and local variability in the abiotic and biotic environment.

In this experimental study, we manipulated water volume in mesocosms, to assess how volume (for simplicity referred to as size), affect phytoplankton communities that dwell in three dimensional habitats (Marquet et al., 1993; Carr et al., 2003). We also manipulated nutrient levels to mimic mesotrophic and hypertrophic conditions in lakes, to 
investigate how the interaction between ecosystem size and anthropogenic stressors can influence phytoplankton diversity. Shallow lakes are the predominant lake type worldwide (Wetzel, 2001), and eutrophication impacts are predicted to increase due to changes in temperature and precipitation regimes associated with climate change, which is influenced by the transport of nutrients from the land to lakes and prolonged water residence time, changing external and internal nutrient loading patterns (Meyer et al., 1999; Ipcc, 2007; Giorgi and Lionello, 2008; Wilhelm and Adrian, 2008; Jeppesen et al., 2009). Thus, the importance of understanding how the interactions between cultural eutrophication and lake size can influence diversity is relevant for society in terms of ecosystem service provisioning (Scheffer et al., 2001). Cultural eutrophication is well-known to induce regime shifts from clear to turbid water in lakes, resulting in a drastic change in ecosystem services such as fisheries, recreation and fresh water quality (Pope et al., 2014).

Our goal was to investigate how the interaction between a stressor (eutrophication) and lake size can influence phytoplankton community composition and diversity using common metrics of species richness, diversity, evenness and total biovolume. Phytoplankton communities respond quickly to environmental change and are indicators of eutrophication (Scheffer et al., 1993; Carpenter et al., 1999; Carvalho et al., 2013). They also show different community dynamics in contrasting ecosystem states (Angeler et al., 2013; Baho et al., 2014), where high nutrient levels generally favour certain species, for instance cyanobacteria. However, the role of ecosystem size in community assembly under the influence of anthropogenic stressors is not comprehensively explored. Here we test the hypothesis that the influence of eutrophication on phytoplankton is dependent on lake size and expect differences in the dynamics of key species and community composition.

\section{METHODS}

\section{Site description}

The mesocosm experiment was conducted in Lake Erken, Sweden for approximately six months (May to early November 2011) corresponding to the ice-free period. Lake Erken is a mesotrophic lake (annual average of $25 \mu \mathrm{g} \mathrm{TP} \mathrm{L}^{-1}$ ) located southeast of Sweden (59 $49^{\prime} 59^{\prime}$ " $\mathrm{N}, 18^{\circ} 33^{\prime} 55^{\prime \prime} \mathrm{E}$ ) and has a surface area of $24 \mathrm{~km}^{2}$, an average depth of $9 \mathrm{~m}$ and a maximum depth of $21 \mathrm{~m}$ (Elliott et al., 2007). Ice cover normally occurs between December and April and the lake has an average water retention time of seven years (Elliott et al., 2007).

\section{Experimental design}

A thorough description of the experimental design can be found in Landkildehus et al. (2014). Briefly, the experiment consisted of two nutrient levels (low, high) crossed with two water depths (shallow, deep). Each treatment [shallow - high nutrients (SH); shallow - low nutrients (SL); deep - high nutrients (DH); deep - low nutrients (DL)] was replicated four times, resulting in a total of 16 mesocosms. The mesocosms consisted of cylindrical impermeable fiberglass tanks (diameter $1.2 \mathrm{~m}$ and a thickness of $4 \mathrm{~mm}$ ) with two different depths 1.2 and 2.2 $\mathrm{m}$ corresponding to the shallow and deep treatments, respectively. A combination of sand and mud from a nearby mesotrophic lake was added as bottom substratum (ca. $10 \mathrm{~cm})$ before being filled with filtered $(500 \mu \mathrm{m})$ lake water to 1020 and 2150 litres, corresponding to two contrasting ecosystem sizes (shallow and deep water levels, respectively). The mesocosms received inocula of plankton (phytoplankton and zooplankton) from five nearby lakes, to enable the development of a diverse flora and fauna, thus addressing one of the major shortcomings of mesocosm experiments regarding the limited representation of species (Stewart et al., 2013). Plankton inocula were collected from five nearby lakes by performing five vertical hauls over the entire water column, using plankton nets of mesh size of $50 \mu \mathrm{m}$. The contents were pooled, mixed and a 1-litre subsample was added to each mesocosm. Similarly, five litres of sediments were collected from the same five lakes and carefully sieved (through $10 \mathrm{~mm}$ ) to avoid introducing fish eggs or large mussels. Submerged vegetation, Eurasian water-milfoil (Myriophyllum spicatum), was collected from the host lake and planted in each mesocosm. Planktivorous fish (juvenile roach (Rutilus rutilus) originating from Lake Erken) were stocked in each mesocosm based on fish biomass (ca. 10 grams per enclosure) and dead fish were replaced when necessary (see Supplementary Table S1-S3 for information about the length and weight of fish individuals). Nets were installed on top of each enclosure to deter birds.

Phosphorus concentrations were adjusted to $25 \mu \mathrm{g}$ $\mathrm{TP} \mathrm{L}^{-1}$ and $200 \mu \mathrm{g} \mathrm{TP} \mathrm{L}{ }^{-1}$, for the low and high nutrients mimicking mesotophic and hypertrophic conditions, respectively. Nitrogen was added to achieve phosphorus to nitrogen ratio of 1:20 (by molecular weight). At the beginning of the experiment, nutrient additions were only required for the high nutrient treatments. Thereafter, monthly nutrient additions were needed to maintain the two nutrient levels throughout the duration of the experiment. Nutrient loss was compensated by monthly nutrient (total phosphorus and total nitrogen) dosing (see Supplementary Table S4 and Figure S1 for observed nutrients values). Nutrient compensation was determined from previous experiments (González Sagrario et al., 2005; Jeppesen et al., 2007b). The water in each mesocosm was continuously mixed using standard 5 watt aquaria pumps. 


\section{Sampling}

Sampling of phytoplankton was initiated on $16^{\text {th }}$ of May 2011. Thereafter samples were taken twice per month resulting in 13 sampling points. Water samples representative of the entire water column were taken with the aid of a Plexiglas ${ }^{\mathbb{B}}$ tube (length $60 \mathrm{~cm}$ and internal diameter of $9.5 \mathrm{~cm}$ ) sampler and pooled. The pooled samples were homogenized and transferred to $50 \mathrm{ml}$ glass bottles and $500 \mathrm{ml}$ plastic bottles for phytoplankton and water chemistry analyses, respectively. The phytoplankton samples were preserved with $0.5 \mathrm{ml}$ of acid Lugol's solutions (Olrik et al., 1989). Phytoplankton was counted using an inverted light microscope and a modified Utermöhl technique commonly used in Scandinavia (Olrik et al., 1989). Taxa were identified to the lowest possible taxonomic unit (generally species). Biovolumes $\left(\mathrm{mm}^{3} \mathrm{~L}^{-1}\right)$ were calculated from geometric conversions following protocols developed by Blomqvist and Herlitz (1998). All water chemistry analyses were conducted by SWEDAC certified laboratories (Swedish Board for Accreditation and Conformity Assessment, SWEDAC; http://swedac.se/en/) at the Erken laboratory, using International (ISO) and European standards when available (http://search.swedac.se/en/accreditations/1239/a000043-001).

\section{Statistical analyses}

All statistical analyses were conducted in R 3.0.2 ( R Development Core Team, 2012). Some mesocosms (one shallow - low nutrient and one deep - low nutrient) were excluded from the statistical analyses due to birds that used the pontoon as resting ground disturbing the experimental nutrient balance with their excrements. In one tank (deep and low nutrient), a non-stocked fish (an adult perch $150 \mathrm{~g}$ ) was discovered and therefore this tank was excluded from analyses. The influence of the birds (despite using nets as a deterrent) and the non-stocked fish could be detected by means of non-metric multidimensional scaling ordination of water quality variables. As a solution, we randomly removed one replicate from each treatment to achieve a balanced experimental design.

\section{Univariate analyses}

Phytoplankton community structure across treatments was characterized with commonly used metrics (richness, diversity, evenness and total biovolume) following the recommendations of Jost (2007) and Tuomisto (2010) to obtain statistically unbiased measures. The Shannon index was transformed into species equivalents by exponentiation to make species richness and diversity trends comparable (Jost, 2007). The exponentiated Shannon index was considered as a measure of 'diversity' reflecting a different ecological process from species richness ('richness') (Tuomisto, 2010). Evenness was obtained dividing 'di- versity' by 'richness', thereby expressing evenness independently from richness (Tuomisto, 2012). We also assessed temporal community turnover across treatments using Bray-Curtis and Sørensen dissimilarities.

Repeated measures analysis of variance (rm-ANOVA) was used to test for statistical differences in the phytoplankton community metrics between treatments. The treatment effects, time effect and their interaction (treatment $x$ time) were investigated. Log transformation was carried out when necessary to fulfil the assumptions of parametric tests. The assumptions of sphericity were similarly considered and when violated Huynh Feldt corrections were implemented (Huynh and Feldt, 1976). When a significant main effect was detected, a posteriori comparisons were made using Tukey HSD test.

\section{Multivariate analyses}

The rm-ANOVA was complemented with permutational multivariate analysis of variance (PERMANOVA) followed by non-metric multidimensional scaling (NMDS) ordination to contrast phytoplankton communities across treatments and time. PERMANOVAs were based on Bray-Curtis and Sørensen similarity matrices of square-root transformed species biovolume matrices with 9999 unrestricted permutations of raw data. Significant differences were inferred at an $\alpha$-level of 0.05 . For both univariate and multivariate comparisons, the interaction terms were considered crucial for inference because they indicate that phytoplankton structure and their temporal patterns during the experiment in low and high nutrient mesocosms vary depending on the size of the mesocosms.

The trajectory of the phytoplankton communities' development across treatments (averaged across replicates) and time were visually assessed using a NMDS ordination based on Bray-Curtis distance matrix. This ordination technique starts by scaling objects in full-dimensional space then reduces these dimensions to a few while maintaining the distance relationship among the objects (Legendre and Legendre, 1998). Spearman's rank correlation analysis was used to investigate the relationship between the individual phytoplankton species (raw biovolume data of individual species) and the univariate community metrics (species richness, diversity, evenness and total biovolume) with NMDS dimensions 1 and 2.

\section{RESULTS}

\section{Univariate analyses}

Univariate analyses showed significant treatment effects for all metrics (Tab. 1, Fig. 1): species richness, diversity, evenness and total biovolume. Post-hoc analysis revealed that the species richness, diversity and evenness were higher in the low nutrient treatments compared to 
the high nutrient treatments irrespective of water depth (Tukey's HSD test: DL $>\mathrm{DH}, \mathrm{SL}>\mathrm{DH}, \mathrm{SL}>\mathrm{SH}, \mathrm{DL}>\mathrm{SH}$, $\mathrm{SH}=\mathrm{DH}, \mathrm{SL}=\mathrm{DL} ; \mathrm{P}<0.05$ ), while the reverse trend was found for total biovolume (Tukey's HSD test: $\mathrm{DL}<\mathrm{DH}$, $\mathrm{SL}<\mathrm{DH}, \mathrm{SL}<\mathrm{SH}, \mathrm{DL}<\mathrm{SH}, \mathrm{SH}=\mathrm{DH}, \mathrm{SL}=\mathrm{DL} ; \mathrm{P}<0.05$ ) (Fig. 2). Moreover, the effect of time was significant for all community metrics, whereas the interaction term (treatment $\mathrm{x}$ time) was significant for species richness and diversity.

Cyanobacteria were the predominant group in the deep and high nutrient mesocosms (Fig. 3), while Charophyta were generally more abundant in the shallow and high nutrient mesocosms. Cyanobacteria peaked almost simultaneously in both high nutrient treatments and reached higher biovolumes in the deeper mesocosms. In contrast, the two low nutrient treatments had comparable phytoplankton development with the exception of Chlorophyta that had higher biovolume in the shallow compared to the deep mesocosms.

\section{Multivariate analyses}

\section{Community composition}

Permutational multivariate analysis of variance based on both Bray-Curtis (considering both presence/absence and biovolume of taxa) and Sørensen dissimilarity matrices (emphasizing presence/absence only) detected significant treatment and time effects, with a significant interaction (Tab. 2). Phytoplankton communities differed among the four treatments (PER-

Tab. 1. Results of repeated-measures ANOVA contrasting phytoplankton community metrics (richness, diversity, evenness and total biovolume) between treatments (deep-high nutrient, deep-low nutrient, shallow-high nutrient and shallow-low nutrient), time (year) and their interactions. Significant terms are in bold.

\begin{tabular}{|c|c|c|c|c|}
\hline Metrics & Statistics & Treatment & Time & Treatment x Time \\
\hline \multirow[t]{4}{*}{ Richness } & df & 3.78 & 12.78 & 36.78 \\
\hline & MS & 153.51 & 132.63 & 25.85 \\
\hline & $\mathrm{F}$ & 24.57 & 22.56 & 4.13 \\
\hline & $\mathrm{P}$ & $<0.001$ & $<0.001$ & $<0.001$ \\
\hline \multirow[t]{4}{*}{ Diversity } & df & 3.78 & 12.78 & 36.78 \\
\hline & MS & 32.93 & 14.86 & 5.16 \\
\hline & $\mathrm{F}$ & 14.84 & 8.24 & 2.32 \\
\hline & $\mathrm{P}$ & $<0.001$ & $<0.001$ & $<0.001$ \\
\hline \multirow[t]{4}{*}{ Evenness } & $\mathrm{df}$ & 3.78 & 12.78 & 36.78 \\
\hline & MS & 0.05 & 0.03 & 0.01 \\
\hline & $\mathrm{F}$ & 5.94 & 9.95 & 1.28 \\
\hline & $\mathrm{P}$ & $<0.001$ & $<0.001$ & 0.33 \\
\hline \multirow[t]{4}{*}{ Total biovolume } & $\mathrm{df}$ & 3.78 & 12.78 & 36.78 \\
\hline & MS & 4.89 & 0.63 & 0.29 \\
\hline & $\mathrm{F}$ & 23.68 & 4.16 & 1.42 \\
\hline & $\mathrm{P}$ & $<0.001$ & $<0.001$ & 0.19 \\
\hline
\end{tabular}

df, degrees of freedom; MS, mean squares; F-ratio and P-levels, with Huynh-Feldt corrections.

Tab. 2. Results of PERMANOVA contrasting phytoplankton communities between treatments (deep-high nutrient, deep-low nutrient, shallow-high nutrient and shallow-low nutrient), time (year) and their interactions. Significant terms are in bold.

\begin{tabular}{|c|c|c|c|c|c|}
\hline Source & Df & SS & MS & F & P-value (MC) \\
\hline \multicolumn{6}{|l|}{ Bray-Curtis } \\
\hline Treatment & 3 & 62205.77 & 20735.26 & 11.15 & 0.0001 \\
\hline Treat $x$ Time & 36 & 131347.65 & 3648.55 & 1.96 & 0.0001 \\
\hline Residual & 104 & 193334.91 & 1858.99 & & \\
\hline Total & 155 & 514614.51 & & & \\
\hline \multicolumn{6}{|l|}{ Sorensen } \\
\hline Treatment & 3 & 41374.95 & 13791.65 & 14.20 & 0.0001 \\
\hline Time & 12 & 90685.31 & 7557.10 & 7.78 & 0.0001 \\
\hline Treat $x$ Time & 36 & 57443.99 & 1595.66 & 1.64 & 0.0001 \\
\hline Residual & 104 & 100943.58 & 970.61 & & \\
\hline Total & 155 & 290447.85 & & & \\
\hline
\end{tabular}

df, degrees of freedom; MS, mean squares; F-ratio and P-levels, with Monte Carlo corrections. 

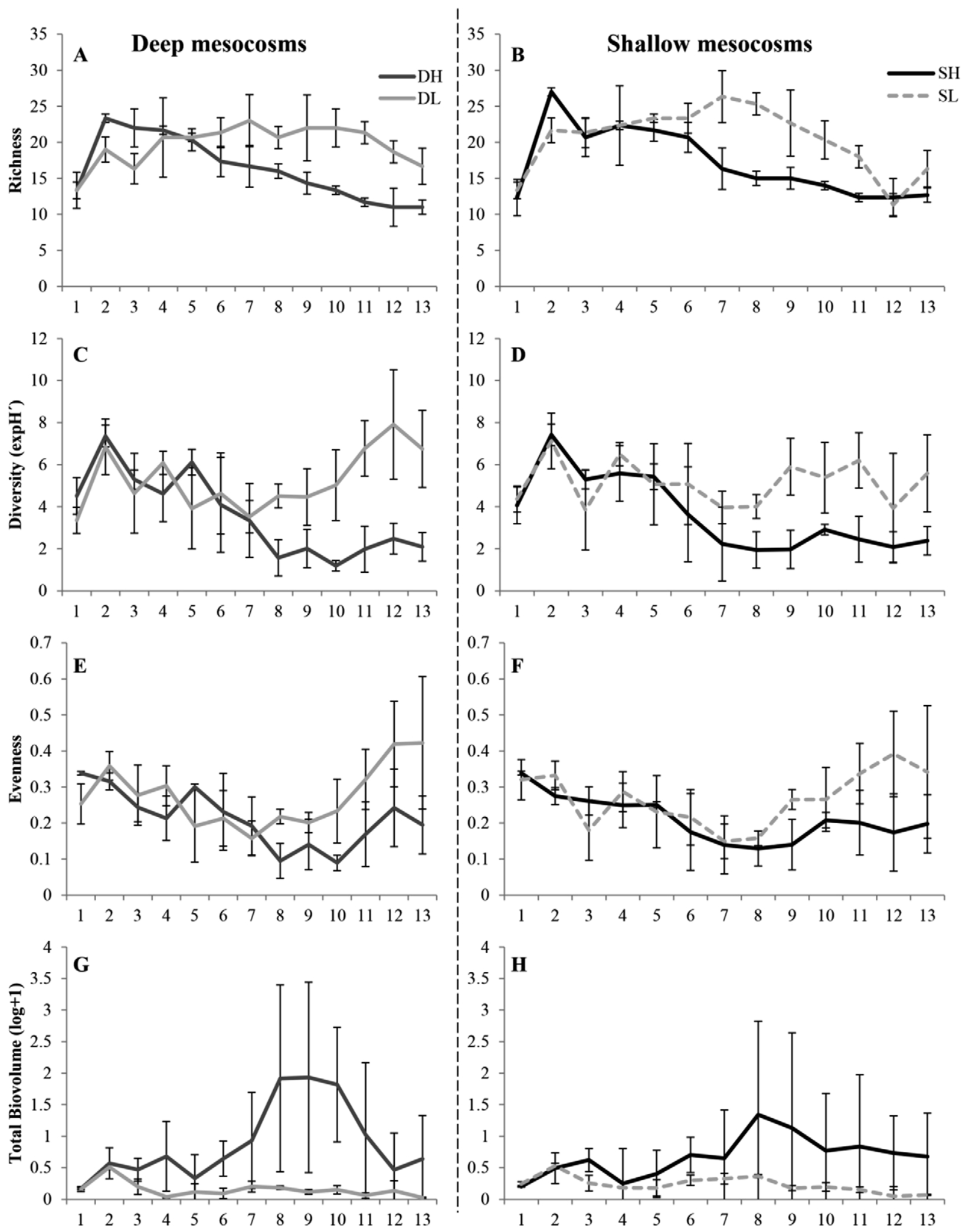

Time points

Fig. 1. Temporal patterns of the community metrics across mesocosms: (a-b) species richness; (c-d) Shannon-Wiener diversity index; (e-f) evenness; (g-h) total biovolume. DH, deep-high nutrient; DL, deep-low nutrient; SH, shallow-high nutrient; SL, shallow-low nutrients treatments. 
MANOVA analysis, $\mathrm{P}<0.05$ ). Effects of nutrient and depth manipulations were visually apparent in non-metric multidimensional scaling (NMDS) ordination when tracking phytoplankton communities' development over time (Fig. 4), which corroborate the results of the PERMAVONA analyses. Phytoplankton communities, similar at the start of the experiment, showed different degrees of divergence over time depending on the treatment (Fig. 4). Nutrient effects were visible along the second NMDS axis, where the low nutrient treatments tended to aggregate towards the top of the figure, whilst the high nutrient treatment clustered in lower right corner (Fig. 4). The Spearman rank correlation analyses showed that 10 species correlated significantly with the first NMDS axis whereas 20 taxa and total biovolume with the second NMDS axis (Tab. 3).

\section{Community turnover}

Generally, community analyses indicated declining turnover rates through time. By contrast, high nutrient treatments exhibited slower turnover rates compared to the low nutrient treatments. The two dissimilarity matrices indicated that treatment effects were only significant for Sørensen (Tukey's HSD test: DL $>$ DH, SL $>$ DH; $\mathrm{P}<0.05$ ), whereas the time effect and the interaction term were significant for both matrices (Fig. 5, Tab. 4).

\section{DISCUSSION}

Nutrient enrichment decreased species richness, diversity and evenness but increased the biovolume of phytoplankton, which corroborates with previous studies (Interlandi and Kilham, 2001; Smith, 2003; Smith and Schindler, 2009). Our findings suggest that common metrics of phytoplankton biodiversity (e.g., species richness and diversity) were similar between size treatments with the same nutrient status. This deviates from the results of previous lake studies that supported the species area theory (Tonn and Magnuson, 1982; Rørslett, 1991; Dodson, 1992; Hoyer and Canfield, 1994; Keller and Conlon, 1994; Post et al., 2000; Bell et al., 2005; Reche et al., 2005; Søndergaard et al., 2005). Despite these findings, phytoplankton species composition markedly differed across size treatments. This does not only support previous studies that inference varies with metrics chosen (univariate $v s$. multivariate) (Angeler and Goedkoop, 2010), but also with the volume of the water column in mesocosms. These
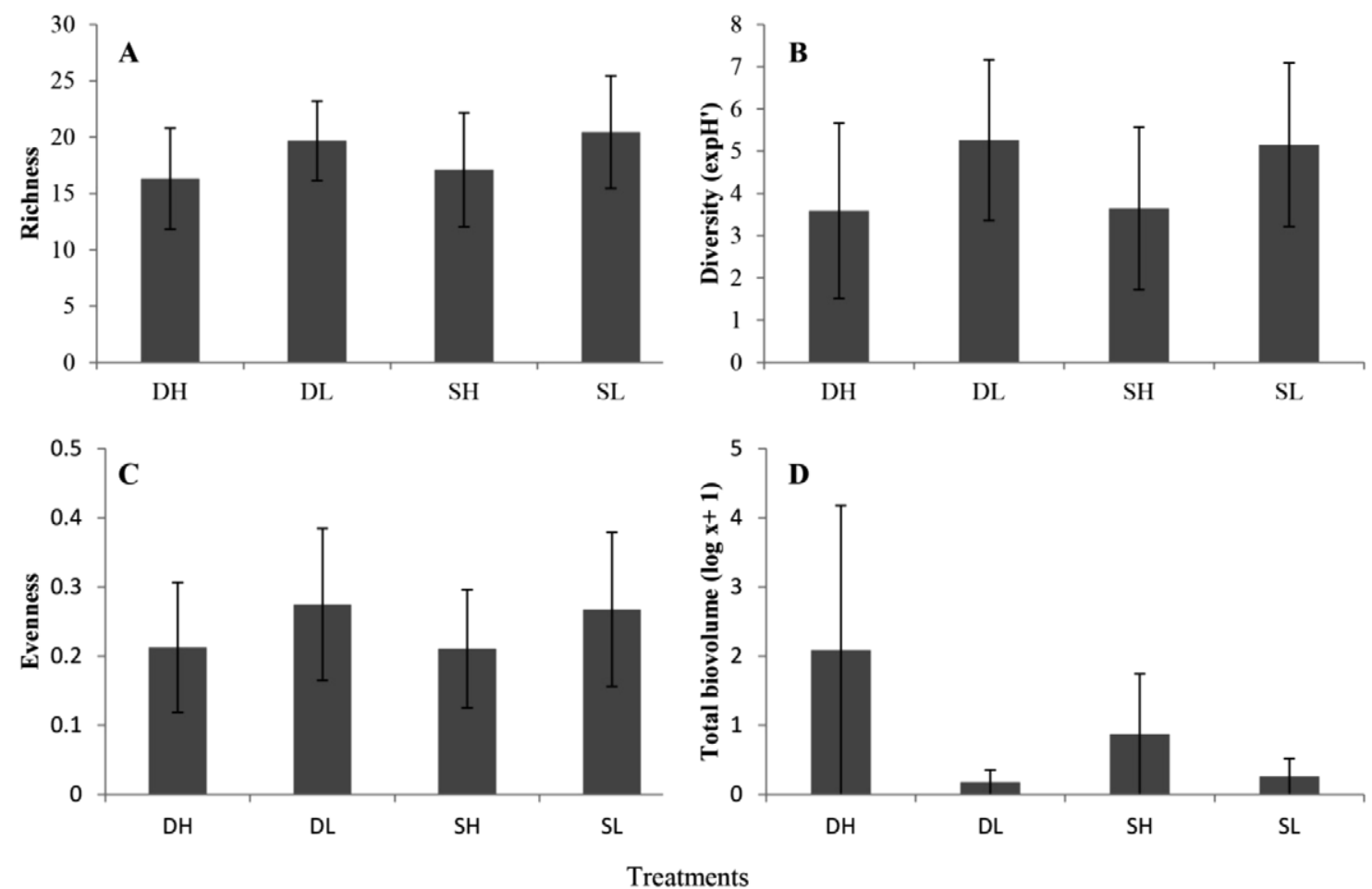

Fig. 2. Comparison of the community metrics across treatments: (a) species richness; (b) Shannon-Wiener diversity index; (c) evenness; (d) total biovolume. DH, deep-high nutrient; DL, deep-low nutrient; SH, shallow-high nutrient; SL, shallow-low nutrients treatments. Shown are mean \pm standard deviation values of the different treatments. 
findings complement and refine insight from previous lakes studies that focused, like terrestrial studies, on the two-dimensional aspect of surface area (Marquet et al., 1993; Carr et al., 2003).

Our results suggest that further cross-system comparisons in the future (e.g., Drakare, Lennon \& Hillebrand, 2006) can benefit from incorporating ecosystems with three-dimensional habitat configuration, specifically marine and freshwater environments but also terrestrial habitats where such dimensionality can vary substantially (e.g., height of grasslands $v$ f forests). At least in a planktonic environment, the three-dimensional habitat configuration mediates important abiotic influences on phytoplankton; that is, light, $\mathrm{pH}$, temperature, oxygen, nutrients and stratification, can show important gradients in the water column (Kalff, 2002; Angeler and Rodrigo, 2004; Angeler et al., 2004; Ingram et al., 2012), which enhances habitat heterogeneity and presumably beta-diversity (Veech and Crist, 2007). In this study, we had identical mixing regimes induced by pumps, and therefore can discard stratification as a variable influencing community dynamics. Instead, light regime in the water column comparable to natural conditions might have been important for phytoplankton distribution and community composition in the water column (Havens et al., 1998; Diehl, 2002).

The differences in phytoplankton community composition between treatments (both univariate and multivariate analyses), indicate interactions between habitat size (volume) and nutrient enrichment. Nevertheless, phytoplankton community development over time appeared to follow the nutrient model proposed by Reynolds $(1980,1984)$ starting with species generally associated with spring bloom, followed by green algae and cyanobacteria. Generally, the effects of nutrient enrichment differed with depth of the water column. Cyanobacteria (mainly Microcystis aeruginosa) were predominant in deep mesocosms, whereas in the shallow nutrient-enriched mesocosms species belonging to the phylum Charophyta (strictly planktonic algae such as species from the genera Euastrum, Elakatothrix and Staurodesmus) reached higher densities than cyanobacteria, presumably due to their preference for higher light intensities (Kruk and Segura, 2012). The inability of cyanobacteria to prevail in the shallow eutrophic mesocosms relative to the deep ones might be attributed to photoinhibition mechanisms, where high light intensities reduce their ability to photosynthesize (Scheffer et al., 1997; Havens et al., 1998).

Tab. 3. Spearman rank correlation analysis showing raw species biovolume and univariate metrics (richness, diversity, evenness and total biovolume) correlating with the NMDS axes. Shown are correlation coefficients (Spearman rho) and associated P-levels: * $\leq 0.05$; $* * \leq 0.01 ; * * * \leq 0.001$. Only significant correlations are shown.

\begin{tabular}{|c|c|c|c|c|c|}
\hline \multicolumn{3}{|c|}{ NMDs axis 1} & \multicolumn{3}{|c|}{ NMDs axis 2} \\
\hline Species & Phylum & Spearman $\rho$ & Species & Phylum & Spearman $\rho$ \\
\hline Scenedesmus acuminatus & Chlorophyta & $-0.41 * * *$ & Scenedesmus acuminatus & Chlorophyta & $-0.45 * * *$ \\
\hline Euastrum validum & Charophyta & $0.37 * *$ & Micractinium pusillum & Chlorophyta & $-0.42 * * *$ \\
\hline Elakatothrix genevensis & Charophyta & $0.36^{* *}$ & Scenedesmus sp. & Chlorophyta & $-0.42 * * *$ \\
\hline Staurodesmus dejectus & Charophyta & $0.33^{*}$ & Microcystis aeruginosa & Cyanobacteria & $-0.40 * * *$ \\
\hline Micractinium pusillum & Chlorophyta & $-0.32 *$ & Total biovolume & & $-0.39 * * *$ \\
\hline Monoraphidium mirabile & Chlorophyta & $-0.30 *$ & Rhodomonas lacustris & Cryptophyta & $0.38 * * *$ \\
\hline Woronichinia compacta & Cyanobacteria & $-0.30 *$ & Actinastrum hantzschii & Chlorophyta & $-0.37 * *$ \\
\hline Franceia ovalis & Chlorophyta & $0.29 *$ & Woronichinia compacta & Cyanobacteria & $-0.36 * *$ \\
\hline Lagerheimia wratislaviensis & Chlorophyta & $-0.28 *$ & Staurastrum tetracerum & Charophyta & $0.35 * *$ \\
\hline \multirow[t]{12}{*}{ Planktothrix agardhii } & Cyanobacteria & $-0.28 *$ & Nephrocytium agardhianum & Chlorophyta & $0.34 * *$ \\
\hline & & & Ankistrodesmus spiralis & Chlorophyta & $0.33 * *$ \\
\hline & & & Crucigenia rectangularis & Chlorophyta & $0.32 *$ \\
\hline & & & Pseudopedinella sp. & Ochrophyta & $0.31 *$ \\
\hline & & & Katablepharis ovalis & Katablepharidophyta & $0.31 *$ \\
\hline & & & Pediastrum duplex & Chlorophyta & $-0.31 *$ \\
\hline & & & Staurodesmus dejectus & Charophyta & $0.31 *$ \\
\hline & & & Largerheimia citriformis & Chlorophyta & $0.30 *$ \\
\hline & & & Dictyosphaerium elegans & Chlorophyta & $0.30 *$ \\
\hline & & & Kirchneriella subcapitata & Chlorophyta & $0.30 *$ \\
\hline & & & Monoraphidium dybowskii & Chlorophyta & $0.29 *$ \\
\hline & & & Largerheimia wratislaviensis & Chlorophyta & $-0.29 *$ \\
\hline
\end{tabular}


Tab. 4. Results of repeated-measures ANOVA contrasting the outcomes of community turnover depicted by Bray-Curtis and Sørensen dissimilarity matrices between treatments (deep-high nutrient, deep-low nutrient, shallow-high nutrient and shallow-low nutrient), time (year) and their interactions. Significant terms are in bold.

\begin{tabular}{|c|c|c|c|c|}
\hline Dissimilarity matrices & Statistics & Treatment & Time & Treatment $x$ Time \\
\hline \multirow{4}{*}{ Bray-Curtis } & df & 3.72 & 11.72 & 33.72 \\
\hline & MS & 0.02 & 0.20 & 0.03 \\
\hline & $\mathrm{F}$ & 1.22 & 12.7 & 1.71 \\
\hline & $\mathrm{P}$ & 0.30 & $<0.001$ & 0.02 \\
\hline \multirow[t]{4}{*}{ Sorensen } & df & 3.72 & 11.72 & 33.72 \\
\hline & MS & 0.02 & 0.12 & 0.01 \\
\hline & $\mathrm{F}$ & 3.36 & 25.42 & 1.94 \\
\hline & $\mathrm{P}$ & 0.03 & $<0.001$ & 0.02 \\
\hline
\end{tabular}

df, degrees of freedom; MS, mean squares; F-ratio and P-levels, with Huynh-Feldt corrections.

\section{Deep mesocosms}

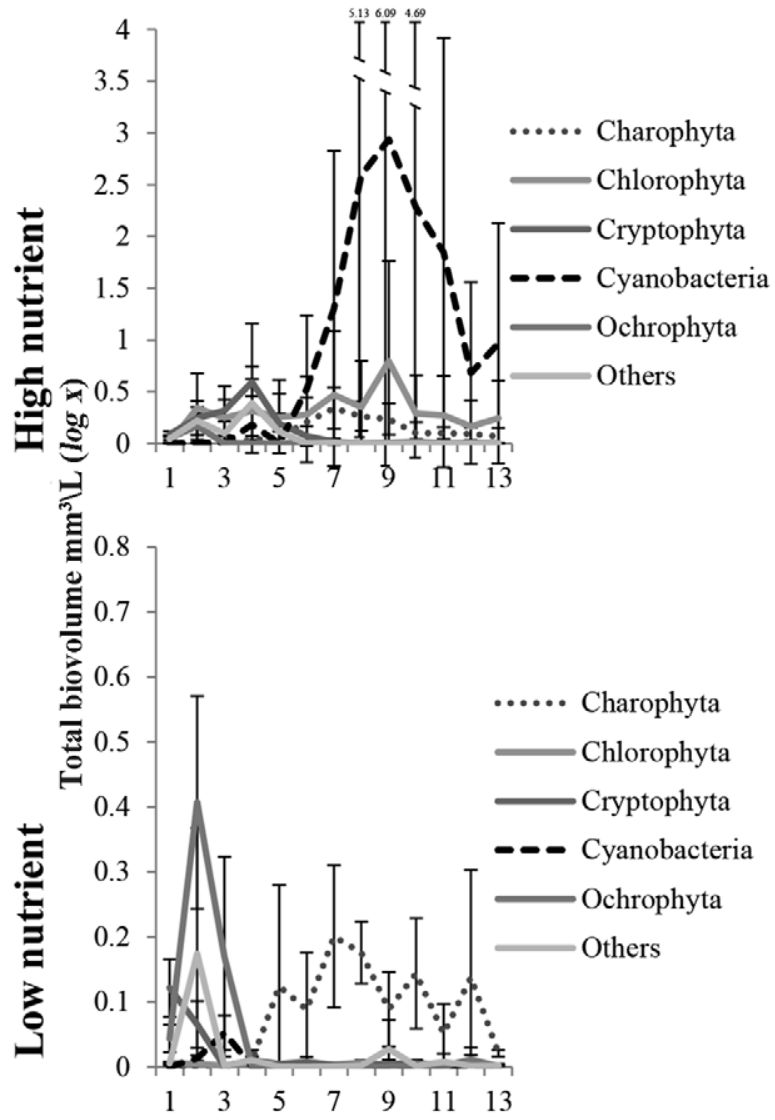

Shallow mesocosms
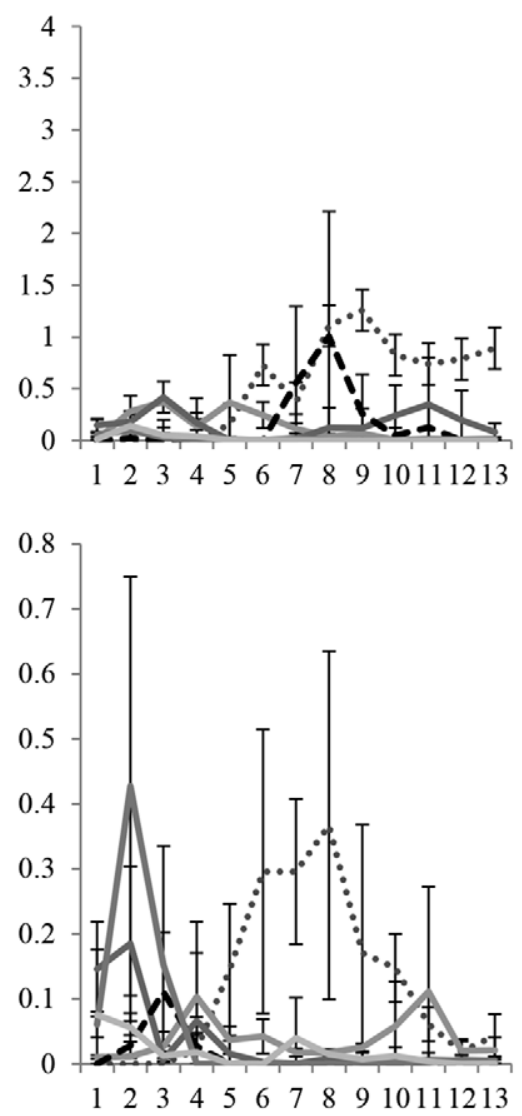

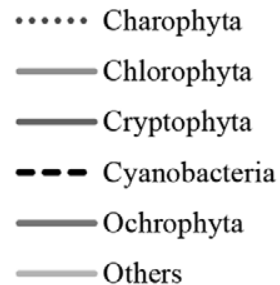

...... Charophyta

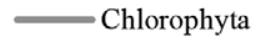

Cryptophyta

- - Cyanobacteria

Ochrophyta

Others

Time points

Fig. 3. The temporal development of the different phytoplankton grouped according to phyla in the four different treatments. Shown are mean \pm standard deviation values of the total biovolume across treatment. Observed that the range of the y-axes differ between the high (0-4) and the low (0-0.8) nutrients treatments are different. The group labelled as 'Others' is the sum of phytoplankton species belonging to the phyla: Choanozoa, Dinophyta, Euglenozoa, Haptophyta and Katablepharidophyta. 


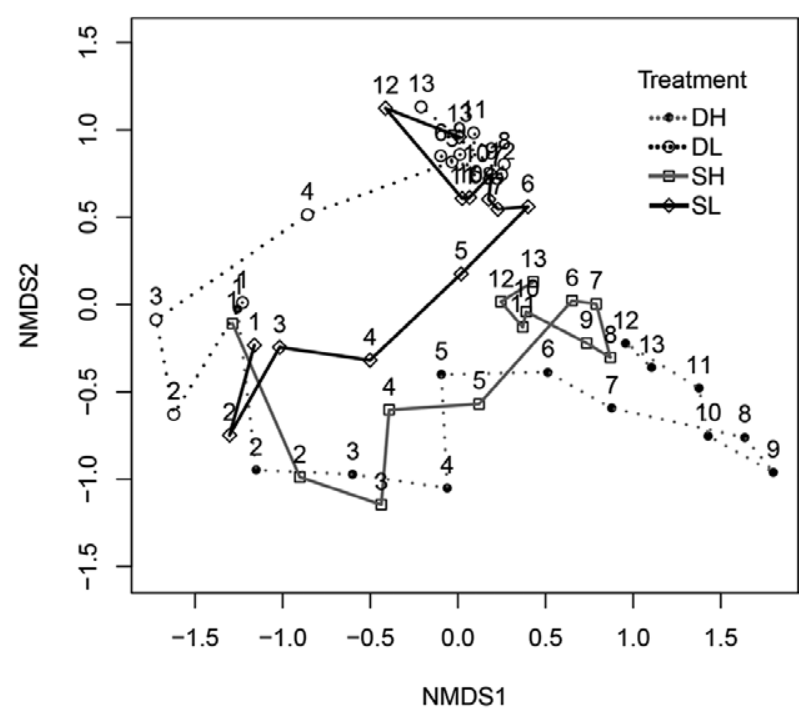

Fig. 4. Nonmetric multidimensional scaling ordination (BrayCurtis) showing the development of phytoplankton communities over time. DH, deep-high nutrient; DL, deep-low nutrient; SH, shallow-high nutrient; SL, shallow-low nutrients treatments. The numbers (1-13) represent the different sampling point. A stress value of 0.09 was obtained.

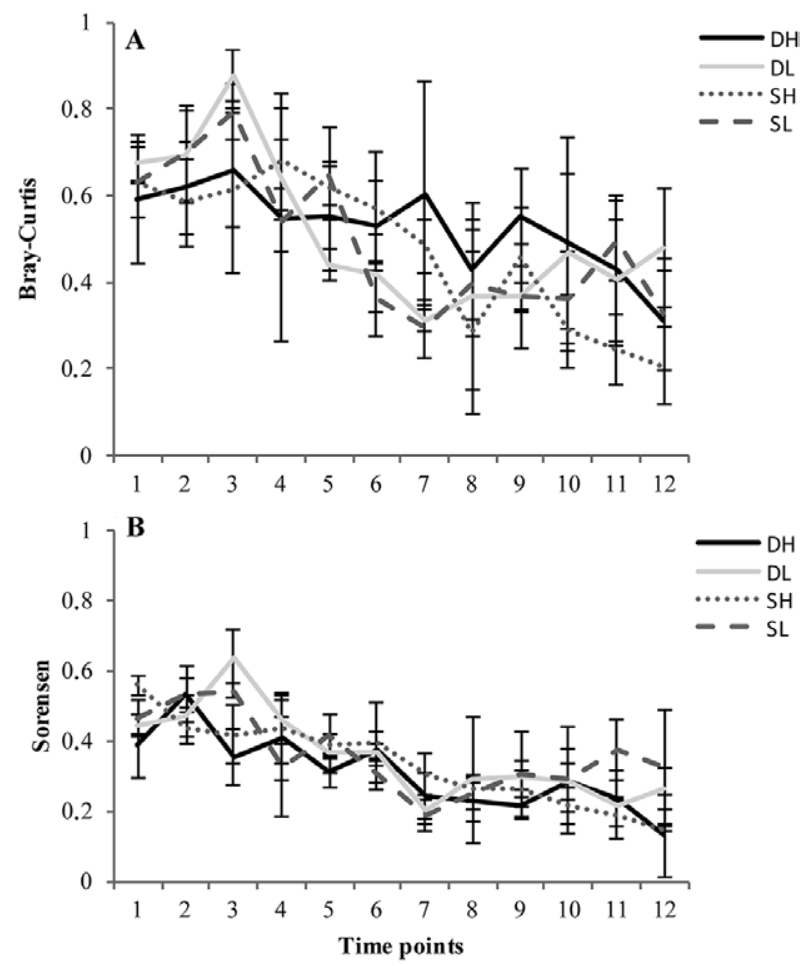

Fig. 5. Phytoplankton communities' turnover based (a) BrayCurtis and (b) Sorensen dissimilarity matrices. DH, deep-high nutrient; DL, deep-low nutrient; SH, shallow-high nutrient; SL, shallow-low nutrients treatments.
However, in favourable conditions (high nutrient and low light intensity), cyanobacteria can to some extent control light regime through self-shading mechanisms by reaching high densities and forming large colonies, where self-shading does not impact their photosynthetic efficiencies as shown by Agusti and Phlips (1992). This may underline a positive feedback that suppresses photoinhibition and create optimum conditions for cyanobacteria to thrive, which has been previously been demonstrated by Veraart et al. (2012).

Anthropogenic disturbances can potentially homogenize communities by favouring competitively superior species (Devictor et al., 2008; Macdougall et al., 2013). Our findings that nutrient enriched mesocosms had lower evenness and community turnover compared to the low nutrient treatments support this conjecture. Despite this, phytoplankton community structure differed markedly between shallow and deep mesocosms with high nutrient status. However, differences were less pronounced between low-nutrient mesocosms of different size, indicating a strong effect of ecosystem size in mediating eutrophication effects in shallow lakes. The decrease in community turnover could be related to seasonal changes. Although a longer study period might provide more insights to the effect of anthropogenic stressors on temporal community turnover, our results partially suggest that nutrient enrichment can interfere and interrupt the gradual seasonal phytoplankton community dynamics by enabling certain species to maintain prolonged dominance (Scheffer and Nes, 2007).

The scale of perception of organisms, which is correlated to their body size (Peters, 1986) might have some implications for species-area relationship concept (Azovsky, 2002). For instance, the study performed by Azovsky (2002) found that smaller organisms (ciliates and diatoms) showed a weaker and less steep increase of species richness with area than larger ones. Thus, for large species groups such as fish, area might be more appropriate whereas volume, better at expressing habitat heterogeneity across the water column, might be more relevant for smaller planktonic organisms. Developing a framework to evaluate habitat heterogeneity in lentic ecosystems, despite not being the scope this study, could contribute to the ongoing discussion on whether heterogeneity is the most important factor that shape species-area relationship (Macarthur and Wilson, 1967; Tews et al., 2004; Whittaker and Fernández-Palacios, 2007; Báldi, 2008).

\section{CONCLUSIONS}

In summary, we found that the effects of nutrient enrichment on phytoplankton diversity and communities were dependent on ecosystem size. The dominance of cyanobacteria, often considered a nuisance algal group by water quality managers (Scheffer et al., 1997) due to their 
wide-ranging impacts, including toxic effects, shading of submerged plants and alteration of food webs (Havens, 2008), is not only dependent on nutrient status but rather on the combination of nutrient and ecosystem size as observed in our experiment. Such interactions increase the uncertainty of global change outcomes related to continued changes in nutrient regimes of lakes (Anderson et al., 2005; Jeppesen et al., 2007a; Jeppesen et al., 2007b) and should therefore be given greater consideration in risk/impact assessment and management. Furthermore, identifying interactions between stressors and ecosystem size can help managers and decision maker to decide when and where to act, as resources (financial and time) are limited (Wilson et al., 2006; Brown et al., 2013; Ghedini et al., 2013; Côté et al., 2016). Priority action must be identified aiming at achieving the highest benefits to with respect to biodiversity and ecosystem functions that are highly valued by society (Wilson et al., 2006; Brown et al., 2013; Ghedini et al., 2013; Côté et al., 2016).

\section{ACKNOWLEDGMENTS}

This study was financed by the EU FP-7 Theme 6 project REFRESH (Adaptive Strategies to Mitigate the Impacts of Climate Change on European Freshwater Ecosystems, Contract No.: 244121, www.refresh.ucl. ac.uk/) and the August T. Larsson foundation of the NJ Faculty (Swedish University of Agricultural Sciences). Additional support by the Swedish Research Councils Formas (2014-1193) and VR (2014-5828) is acknowledged. We are thankful for the assistance of the Erken Lab staff and Sebastian Sonesten during field work and the help of taxonomic experts Eva Herlitz and Isabel Quintana when identifying phytoplankton.

The Nebraska Cooperative Fish and Wildlife Research Unit is jointly supported by a cooperative agreement between the U.S. Geological Survey, the Nebraska Game and Parks Commission, the University of Nebraska-Lincoln, the United States Fish and Wildlife Service and the Wildlife Management Institute.

\section{REFERENCES}

Agusti S, Phlips EJ, 1992. Light absorption by cyanobacteria: Implications of the colonial growth form. Limnol. Oceanogr. 37:434-441.

Anderson NJ, Jeppesen E, Sondergaard M, 2005. Ecological effects of reduced nutrient loading (oligotrophication) on lakes: an introduction. Freshwater Biol. 50:1589-1593.

Angeler DG, Allen CR, Rojo C, Alvarez-Cobelas M, Rodrigo MA, Sanchez-Carrillo S, 2013. Inferring the relative resilience of alternative states. PLoS One 8:e77338.

Angeler DG, Alvarez-Cobelas M, 2005. Island biogeography and landscape structure: Integrating ecological concepts in a landscape perspective of anthropogenic impacts in temporary wetlands. Environ. Pollut. 138:420-424.

Angeler DG, Goedkoop W, 2010. Biological responses to liming in boreal lakes: an assessment using plankton, macroinvertebrate and fish communities. J. Appl. Ecol. 47:478-486.

Angeler DG, Rodrigo MA, 2004. Ramp disturbance-ramp response: a simple model for wetland disturbance ecology. Mar. Freshwater Res. 55:33-37.

Angeler DG, Sánchez-Carrillo S, Rodrigo MA, Viedma O, Alvarez-Cobelas M, 2004. On the Importance of water depth, macrophytes and fish in wetland picocyanobacteria regulation. Hydrobiologia 549:23-32.

Azovsky AI, 2002. Size-dependent species-area relationships in benthos: is the world more diverse for microbes? Ecography 25:273-282.

Baho DL, Drakare S, Johnson RK, Allen CR, Angeler DG, 2014. Similar resilience attributes in lakes with different management practices. PLoS One 9:10.

Báldi A, 2008. Habitat heterogeneity overrides the species-area relationship. Journal of Biogeography 35:675-681.

Bell T, Ager D, Song J-I, Newman JA, Thompson IP, Lilley AK, Van Der Gast CJ, 2005. Larger islands house more bacterial taxa. Science 308:1884.

Blomqvist P, Herlitz E. 1998. Methods for quantitative assessment of phytoplankton in freshwaters, part 2 (Report 4861). Naturvårdsverket (Swedish Environmental Protection Agency), Stockholm.

Brown CJ, Saunders MI, Possingham HP, Richardson AJ, 2013. Managing for interactions between local and global stressors of ecosystems. PLoS One 8:e65765.

Carpenter SR, Ludwig D, Brock WA, 1999. Management of eutrophication for lakes subject to potentially irreversible change. Ecol. Appl. 9:751-771.

Carr MH, Neigel JE, Estes JA, Andelman S, Warner RR, Largier JL, 2003. Comparing marine and terrestrial ecosystems: implications for the design of coastal marine reserves. Ecol. Appl. 13:90-107.

Carvalho L, Poikane S, Solheim AL, Phillips G, Borics G, Catalan J, De Hoyos C, Drakare S, Dudley BJ, Jarvinen M, Laplace-Treyture C, Maileht K, Mcdonald C, Mischke U, Moe J, Morabito G, Noges P, Noges T, Ott I, Pasztaleniec A, Skjelbred B, Thackeray SJ, 2013. Strength and uncertainty of phytoplankton metrics for assessing eutrophication impacts in lakes. Hydrobiologia 704:127-140.

Confer JL, Kaaret T, Likens GE, 1983. Zooplankton diversity and biomass in recently acidified lakes. Can. J. Fish. Aquat. Sci. 40:36-42.

Côté IM, Darling ES, Brown CJ, 2016. Interactions among ecosystem stressors and their importance in conservation. P. Roy. Soc. B-Biol. 283. DOI: 10.1098/rspb.2015.2592

Devictor V, Julliard R, Clavel J, Jiguet F, Lee A, Couvet D, 2008. Functional biotic homogenization of bird communities in disturbed landscapes. Global Ecol. Biogeogr. 17:252-261.

Diehl S, 2002. Phytoplankton, light, and nutrients in a gradient of mixing depths: theory. Ecology 83:386-398.

Dodson S, 1992. Predicting crustacean zooplankton species richness. Limnol. Oceanogr. 37:848-856.

Drakare S, Lennon JJ, Hillebrand H, 2006. The imprint of the geographical, evolutionary and ecological context on species-area relationships. Ecol. Lett. 9:215-227. 
Elliott JA, Persson I, Thackeray SJ, Blenckner T, 2007. Phytoplankton modelling of Lake Erken, Sweden by linking the models PROBE and PROTECH. Ecol. Modell. 202: 421-426.

Frost T, Deangelis D, Bartell S, Hall D, Hurlbert S. 1988. Scale in the design and interpretation of aquatic community research, p. 229-258. In: S. Carpenter (ed.), Complex interactions in lake communities. Springer, New York.

Ghedini G, Russell BD, Connell SD, 2013. Managing local coastal stressors to reduce the ecological effects of ocean acidification and warming. Water 5:1653-1661.

Giorgi F, Lionello P, 2008. Climate change projections for the Mediterranean region. Glob. Planet. Change 63:90-104.

González Sagrario MA, Jeppesen E, Gomà J, Søndergaard M, Jensen JP, Lauridsen T, Landkildehus F, 2005. Does high nitrogen loading prevent clear-water conditions in shallow lakes at moderately high phosphorus concentrations? Freshwater Biol. 50:27-41.

Hansen AJ, Neilson RP, Dale VH, Flather CH, Iverson LR, Currie DJ, Shafer S, Cook R, Bartlein PJ, 2001. Global Change in forests: responses of species, communities, and biomes: interactions between climate change and land use are projected to cause large shifts in biodiversity. BioScience 51:765-779.

Havens KE, 2008. Cyanobacteria blooms: effects on aquatic ecosystems, p. 733-747. in: H.K. Hudnell (ed.), Cyanobacterial harmful algal blooms: state of the science and research needs. Springer, New York.

Havens KE, Phlips EJ, Cichra MF, Li B-L, 1998. Light availability as a possible regulator of cyanobacteria species composition in a shallow subtropical lake. Freshwater Biol. 39:547-556.

Hoyer M, Canfield D, Jr., 1994. Bird abundance and species richness on Florida lakes: influence of trophic status, lake morphology, and aquatic macrophytes. Hydrobiologia 279280:107-119.

Huynh H, Feldt LS, 1976. Estimation of the box correction for degrees of freedom from sample data in randomized block and split-plot designs. J. Educ. Stat. 1:69-82.

Ingram T, Hudson AG, Vonlanthen P, Seehausen O, 2012. Does water depth or diet divergence predict progress towards ecological speciation in whitefish radiations? Evol. Ecol. Res. 14:487-502.

Interlandi SJ, Kilham SS, 2001. Limiting resources and the regulation of diversity in phytoplankton communities. Ecology 82:1270-1282.

Ipcc. 2007. Intergovernmental Panel on Climate Change, Climate Change: Contribution of Working Group iii to the Fourth Assessment Report of the Intergovernmental Panel on Climate Change. Cambridge University Press.

Jeppesen E, Kronvang B, Meerhoff M, Sondergaard M, Hansen KM, Andersen HE, Lauridsen TL, Liboriussen L, Beklioglu M, Ozen A, Olesen JE, 2009. Climate change effects on runoff, catchment phosphorus loading and lake ecological state, and potential adaptations. J. Environ. Qual. 38:1930-1941.

Jeppesen E, Meerhoff M, Jacobsen BA, Hansen RS, Sondergaard M, Jensen JP, Lauridsen TL, Mazzeo N, Branco CWC, 2007a. Restoration of shallow lakes by nutrient control and biomanipulation-the successful strategy varies with lake size and climate. Hydrobiologia 581:269-285.
Jeppesen E, Sondergaard M, Meerhoff M, Lauridsen TL, Jensen JP, 2007b. Shallow lake restoration by nutrient loading reduction - some recent findings and challenges ahead. Hydrobiologia 584:239-252.

Jost L, 2007. Partitioning diversity into independent alpha and beta components. Ecology 88:2427-2439.

Kalff J, 2002. Limnology: inland water ecosystems. Prentice Hall, Upper Saddle River : 592 pp.

Keller W, Conlon M, 1994. Crustacean zooplankton communities and lake morphometry in precambrian shield lakes. Can. J. Fish. Aquat. Sci. 51:2424-2434.

Kruk C, Segura A, 2012. The habitat template of phytoplankton morphology-based functional groups. Hydrobiologia 698:191-202.

Landkildehus F, Søndergaard M, Beklioğlu M, Adrian R, Angeler DG, Hejzlar J, Papastergiadou E, Zingel P, Çakiroğlu Aİ, Scharfenberger U, Drakare S, Nõges T, Šorf M, Stefanidis K, Tavşanoğlu ÜN, Trigal C, Mahdy A, Papadaki C, Tuvikene L, Larsen SE, Kernan M, Jeppesen E, 2014. Climate change effects on shallow lakes: design and preliminary results of a cross-European climate gradient mesocosm experiment. Eston. J. Ecol. 63:71-89.

Legendre P, Legendre L, 1998. Ordination in reduced space, p. 387-480. In: L. Pierre and L. Louis (eds.), Developments in environmental modelling. Elsevier, Amsterdam.

Leibold MA, Holyoak M, Mouquet N, Amarasekare P, Chase J, Hoopes M, Holt R, Shurin J, Law R, Tilman D, 2004. The metacommunity concept: a framework for multi-scale community ecology. Ecolo. Lett. 7:601-613.

Macarthur R, Wilson E, 1967. The theory of island biogeography. Princeton University Press, Princeton: 224 pp

Macdougall AS, Mccann KS, Gellner G, Turkington R, 2013. Diversity loss with persistent human disturbance increases vulnerability to ecosystem collapse. Nature 494:86-89.

Marquet P, Fortin M-J, Pineda J, Wallin D, Clark J, Wu Y, Bollens S, Jacobi C, Holt R. 1993. Ecological and Evolutionary consequences of patchiness: a marine-terrestrial perspective, p. 277-304. In: S. Levin, T. Powell and J. Steele (eds.), Patch dynamics. Lecture Notes in Biomathematics. Springer, Berlin.

Meyer JL, Sale MJ, Mulholland PJ, Poff NL, 1999. Impacts of climate change on aquatic ecosystem functioning and health. J. Am. Water Resour. Assoc. 35:1373-1386.

Olrik KP, Blomqvist P, Brettum P, Cronberg G, Eloranta P, 1989. Methods for quantitative assessment of phytoplankton in freshwaters, Part I. Swedish Environmental Protection Agency, Stockholm.

Peters RH, 1986. The ecological implications of body size. Cambridge University Press, Cambridge: 329 pp.

Pope KL, Allen CR, Angeler DG, 2014. Fishing for resilience. T. Am. Fish. Soc. 143:467-478.

Post DM, Pace ML, Hairston NG, 2000. Ecosystem size determines food-chain length in lakes. Nature 405:1047-1049.

R Development Coreteam. 2012. R: A language and environment for statistical computing. Vienna, Austria: R Foundation for Statistical Computing. Retrieved from http://www. R-project.org.

Reche I, Pulido-Villena E, Morales-Baquero R, Casamayor EO, 2005. Does ecosystem size determine aquatic bacteria richness? Ecology 86:1715-1722. 
Reynolds CS, 1980. Phytoplankton assemblages and their periodicity in stratifying lake systems. Ecography 3:141-159.

Reynolds CS, 1984. Phytoplankton periodicity: the interactions of form, function and environmental variability. Freshwater Biol. 14:111-142.

Rørslett B, 1991. Principal determinants of aquatic macrophyte richness in northern European lakes. Aquat. Bot. 39:173-193.

Scheffer M, Carpenter S, Foley JA, Folke C, Walker B, 2001. Catastrophic shifts in ecosystems. Nature 413:591-596.

Scheffer M, Hosper SH, Meijer ML, Moss B, Jeppesen E, 1993. Alternative equilibria in shallow lakes. Trends Ecol. Evol. $8: 275-279$

Scheffer M, Nes EH, 2007. Shallow lakes theory revisited: various alternative regimes driven by climate, nutrients, depth andlake size. Hydrobiologia 584:455-466.

Scheffer M, Rinaldi S, Gragnani A, Mur LR, Van Nes EH, 1997. On the dominance of filamentous Cyanobacteria in shallow, turbid lakes. Ecology 78:272-282.

Smith V, 2003. Eutrophication of freshwater and coastal marine ecosystems a global problem. Environ. Sci. Pollut. Res. 10:126-139.

Smith VH, Schindler DW, 2009. Eutrophication science: where do we go from here? Trends Ecol. Evol. 24:201-207.

Soininen J, 2014. A quantitative analysis of species sorting across organisms and ecosystems. Ecology 95:3284-3292.

Sprules WG, 1977. Crustacean Zooplankton communities as indicators of limnological conditions an approach using principal component analysis. J. Fish. Res. Board Can. 34:962-975.

Stewart RIA, Dossena M, Bohan DA, Jeppesen E, Kordas RL, Ledger ME, Meerhoff M, Moss B, Mulder C, Shurin JB, Suttle B, Thompson R, Trimmer M, Woodward G. 2013. Mesocosm Experiments as a Tool for Ecological ClimateChange Research, p. 71-181. In: G. Woodward and E.J. Ogorman (eds.), Advances in ecological research. 48. Global change in multispecies systems, Pt 3. Advances in ecological research. Elsevier, Amsterdam.

Søndergaard M, Jeppesen E, Jensen JP, 2005. Pond or lake: does it make any difference? Arch. Hydrobiol. 162:143-165.

Tews J, Brose U, Grimm V, Tielbörger K, Wichmann M, Schwager M, Jeltsch F, 2004. Animal species diversity driven by habitat heterogeneity/diversity: the importance of keystone structures. J. Biogeogr. 31:79-92.

Tonn WM, Magnuson JJ, 1982. Patterns in the species composition and richness of fish assemblages in northern Wisconsin lakes. Ecology 63:1149-1166.

Tuomisto H, 2010. A diversity of beta diversities: straightening up a concept gone awry. Part 1 . Defining beta diversity as a function of alpha and gamma diversity. Ecography 33:2-22.

Tuomisto H, 2012. An updated consumer's guide to evenness and related indices. Oikos 121:1203-1218.

Veech JA, Crist TO, 2007. Habitat and climate heterogeneity maintain beta-diversity of birds among landscapes within ecoregions. Global Ecol. Biogeogr. 16:650-656.

Veraart AJ, Faassen EJ, Dakos V, Van Nes EH, Lurling M, Scheffer M, 2012. Recovery rates reflect distance to a tipping point in a living system. Nature 481:357-359.

Wetzel RG, 2001. Shallow lakes and ponds, p. 625-630. In: R.G. Wetzel (ed.), Limnology, $3^{\text {rd }}$ ed. Academic Press.

Whittaker RJ, Fernández-Palacios JM, 2007. Island biogeography: ecology, evolution, and conservation. Oxford University Press, Oxford: 416 pp.

Wilhelm S, Adrian R, 2008. Impact of summer warming on the thermal characteristics of a polymictic lake and consequences for oxygen, nutrients and phytoplankton. Freshwater Biol. 53:226-237.

Wilson KA, Mcbride MF, Bode M, Possingham HP, 2006. Prioritizing global conservation efforts. Nature 440:337-340. 